\title{
Evaluation of metal removal efficiency and its influence in the physicochemical parameters at two sewage treatment plants
}

\author{
Angelo R. F. Pipi • Aroldo G. Magdalena • \\ Giselda P. Giafferis • Gustavo H. R. da Silva • \\ Marina Piacenti-Silva $(\mathbb{D})$
}

Received: 11 July 2017 /Accepted: 22 March 2018/Published online: 3 April 2018

C) Springer International Publishing AG, part of Springer Nature 2018

\begin{abstract}
In sewage treatment plants, physicochemical parameters are highly controlled since treated sewage can be returned to water bodies or reused. In addition, pollutants such as heavy metals also deserve attention due to their potential toxicity. In general, these characteristics of sewage and treated water are evaluated independently, with the support of Brazilian legislation that does not require a routine for the analysis of metals as frequent as for the physicochemical parameters. In this work, 66 samples of raw sewage, treated sewage, and effluents from two treatment plants in the city of Bauru, São Paulo, Brazil, were evaluated to assess the efficiency of the treatment plants in the removal of metals. In
\end{abstract}

\section{A. R. F. Pipi}

Pró-Reitoria de Pesquisa e Pós Graduação (PRPPG), Universidade do Sagrado Coração (USC), Bauru, São Paulo 17011-160, Brazil

A. G. Magdalena

Faculdade de Ciências, Departamento de Química, Universidade Estadual Paulista (Unesp), Bauru, São Paulo 17033-360, Brazil

\section{G. P. Giafferis}

Departamento de Água e Esgoto de Bauru, Prefeitura de Bauru,

Bauru, São Paulo 17012-020, Brazil

G. H. R. da Silva

Faculdade de Engenharia, Departamento de Engenharia de Civil, Universidade Estadual Paulista (Unesp), Bauru, São Paulo 17033-360, Brazil

\section{Piacenti-Silva $(\bowtie)$}

Faculdade de Ciências, Instituto de Pesquisas Meteorológicas (IPMet), Departamento de Física, Universidade Estadual Paulista (Unesp), Bauru, São Paulo 17033-360, Brazil

e-mail: marina.piacenti@unesp.br addition, the influence of these pollutants on the quantification of physicochemical parameters was evaluated. The quantification of metals was performed using inductively coupled plasma optical spectroscopy (ICPOES), and Spearman's test was applied to evaluate correlation between physicochemical parameters and metal content. The main metals found in the samples were $\mathrm{Ba}, \mathrm{Mn}, \mathrm{Zn}, \mathrm{Cu}, \mathrm{Se}, \mathrm{Fe}$, and $\mathrm{Al}$. The results indicate that concentrations of metals in the aquatic environment can significantly affect the physicochemical parameters, since high concentrations of metals can interfere mainly in the $\mathrm{pH}$, chemical oxygen demand, and dissolved oxygen.

Keywords Heavy metal Physicochemical parameters . Sewage treatment plant

\section{Introduction}

The knowledge and concern about environmental contamination by metals have long been the subject of study and control, as these elements can be harmful to both the environment and human health, especially since when in high concentrations, they become toxic (Nriagu and Pacyna 1988; Järup 2003; de Vives et al. 2006; Vasconcellos et al. 2007; Khan 2011).

The major routes of human exposure to metals are oral and inhaled. Regarding the metals widely found in the aquatic system, epidemiological studies suggest a possible association between aluminum (Al) and Alzheimer's disease, with $\mathrm{Al}$ being a risk factor for the 
development or acceleration of the disorder (Campbell 2002). Contact with barium (Ba) can cause changes and even paralyze the heart rhythm because it is not an essential element to humans (CETESB 2013). Lead $(\mathrm{Pb})$ can affect almost all organs, with the central nervous system being the most sensitive in both children and adults. The main effects of exposure to $\mathrm{Pb}$ are weakness, irritability, nausea, abdominal pain, and anemia (Capellini et al. 2008; CETESB 2013). Copper (Cu) and zinc $(\mathrm{Zn})$ are essential elements for living organisms; however, the ingestion of water containing high concentrations of these metals can produce nausea, vomiting, abdominal pain, and diarrhea, especially in children (CETESB 2013). At high concentrations in the body, these metals can induce changes in DNA causing even cancer (Järup 2003; Englert 2004).

Heavy metals are persistent pollutants of the aquatic ecosystem due to their resistance to decomposition under natural conditions (Khan 2011). Their presence in these environments is the result of several factors, such as rock leaching, atmospheric deposition, and urban and industrial wastewater discharge (Khan 2011; Kumar et al. 2014). In particular, with the rapid population growth and increased sewage disposal, this becomes the final destination of large amounts of metals. High levels of metals present in water and sewage sludge have been observed worldwide, so some sewage treatment plants have already been designed to treat these dangerous pollutants in the aquatic system, for example, through retention basins for removing particulate matter by sedimentation (El Samrani et al. 2008; Mulchandani and Westerhoff 2016). In general, sewage treatment plants perform procedures to adequately suit the effluents so that they do not cause environmental impacts that modify the physical, chemical, and biological characteristics of the receiving body that will receive this treated sewage.

Recognizing the levels of metals in sewage is important for their removal, treatment, and final disposal to fluvial bodies or even water reuse. In particular, evaluating the physical and chemical analysis parameters together with the levels of metals is fundamental since both factors may potentially have their values modified depending on the observed concentrations from one another.

Therefore, the objective of this study was to appraise the presence and concentration of metals in two treatment sewage (or wastewater) plants in Bauru to evaluate the influence of these metals on routine physicochemical parameters.

\section{Experimental}

Description of the study areas

Bauru is located in São Paulo state, Brazil, with an area of $673,488 \mathrm{~km}^{2}$, and total population about 369,368 (IBGE 2016). In Bauru, 90\% of all sewage is dumped on the Bauru River and its tributaries. It is released about $1000 \mathrm{~L} \mathrm{~s}^{-1}$ of sewage on rivers without treatment $(85 \%$ from residential and 15\% from industrial sources). Recently, two sewage or wastewater treatment plants (WWTPs) from the Bauru Water Department treat $10 \%$ of sewage from the city. These WWTPs are in two different locations situated at $22^{\circ} 16^{\prime} 02.0^{\prime \prime} \mathrm{S}$ $49^{\circ} 05^{\prime} 13.0^{\prime \prime} \mathrm{W}$ and $22^{\circ} 13^{\prime} 39.0^{\prime \prime} \mathrm{S} 49^{\circ} 12^{\prime} 46.0^{\prime \prime} \mathrm{W}$ and are named respectively Candeia (ETECan) and Tibiriçá (ETETib) with flow rates of 40.00 and $6.00 \mathrm{~L} \mathrm{~s}^{-1}$, respectively. The WWTP Candeia involves bar screens, sand separator, Parshall flume, pumping station, sand drying beds, UASB reactor, biological aerated filter, secondary sedimentation tank, disinfection using sodium hypochlorite, contact chamber, and aeration ladder. The WWTP Tibiriçá is composed by bar screens, sand separator, Parshall flume, primary sedimentation tank, upflow anaerobic filter, constructed wetlands, and sludge drying bed.

After treatment, ETECan and ETETib effluents are released in Pau D'alho and Sossego streams respectively, both classified as class II.

\section{Sample collection}

A total of 66 samples was collected weekly in the period between July 2015 and September 2015. Samples were collected at three different points from both sewage treatment plants: (i) raw sewage (grating), (ii) treated effluent (output), and (iii) treated effluent disposal in river after (downstream).

The samples were collected by a stainless steel collector and transferred to polypropylene bottles and kept refrigerated until the moment of analysis. The procedure for collecting the samples was carried out according to the guidelines of the Standard Methods for the Examination of Water and Wastewater (APHA 2005), so a representative sample of the surface water was obtained. As the surface water source was accessible by wading, the collection was done by direct dipping of the sample container into the stream. For metal analysis, $1.0 \mathrm{~L}$ of sample was collected and stored with the addition of 
$1.5 \mathrm{~mL}$ of nitric acid (APHA 2005). For the physicochemical analysis, a further $2.0 \mathrm{~L}$ of sample was collected. The $\mathrm{pH}$, temperature, and dissolved oxygen parameters were checked at the collection site, and the other physical and chemical analyses were performed in the laboratory.

Analytical methods for physicochemical parameters

The physicochemical analyses were carried out at the Wastewater Laboratory of the Department of Civil Engineering, School of Engineering. In all samples were performed tests to determine the following parameters: temperature, $\mathrm{pH}$, conductivity, turbidity, chemical oxygen demand (COD), dissolved oxygen, and ammonia content. All analyses were performed in triplicate following the analytical methods described in the Standard Methods for the Examination of Water and Wastewater (APHA 2005).

The temperature and $\mathrm{pH}$ were measured using a $\mathrm{pH}$ meter by field potentiometric determination. The conductivity analyses were performed by potentiometric determination through a conductivity meter Thermo Electron Corporation Orion 3 Star. The turbidity evaluations were performed in the turbidimeter $\mathrm{HACH}$ $2100 N$. In the COD analysis using the Hach method, with the Hach COD digestion solution kit, the Hach reactor was used for the digestion and a spectrophotometer of the same brand, model DR 6000, for absorbance measurement. The procedure duration for the COD analysis is $2 \mathrm{~h}$ at a temperature of $150{ }^{\circ} \mathrm{C}$ using $2 \mathrm{~mL}$ of each sample by analysis. Dissolved oxygen analyses were performed by field potentiometric determination. Finally, for the quantification of ammonia, the multiparameter Thermo Scientific Orion 720 A+ with probe for Ammonia analysis was used.

\section{Sample digestion for metal analysis}

For metal quantification, the samples were submitted to a digestion process, in which aliquots of $10 \mathrm{~mL}$ of the samples were digested in a digestion block at $110{ }^{\circ} \mathrm{C}$,

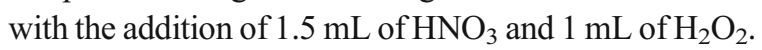
Samples were digested in triplicate. The digested solutions were then replenished to $10 \mathrm{~mL}$ and stored in polypropylene tubes. All recipients used were precleaned in $5 \% \mathrm{HNO}_{3}$ for $24 \mathrm{~h}$, then rinsed with Milli$\mathrm{Q}$ water (APHA 2005).
Instrumental analysis

Metal content was analyzed by inductively coupled plasma optical spectrometry (ICP-OES) technique, at the Wastewater Laboratory of the Department of Civil Engineering, School of Engineering. Multi-element standard solutions certified and traceable to NIST (Specsol®) were used to perform calibration. In each measurement, samples were analyzed in triplicate, and analyses of a blank (Mili-Q water) was also performed. The standard deviation obtained after the triplicate analyses was between 10 and $15 \%$ for all samples. To check accuracy of measurements, the reference material used were multi-element solutions purchased from Perkin Elmer. Although they are already liquid, these reference materials were subjected to the same process of digestion of sewage samples with $\mathrm{HNO}_{3}$ and $\mathrm{H}_{2} \mathrm{O}_{2}$, to verify any possible contamination during the process. Accuracy tests showed that sample preparation and instrumentation conditions provided good levels of accuracy and precision, with differences of up to $11 \%$ of the nominal value from multi-element solutions.

\section{Statistical analysis}

To evaluate the correlation between metal concentration and physicochemical parameters, the Spearman test was performed with significance levels of 1 and 5\% (Conover 1980). This test is appropriate since distributions of metal concentrations as well as physicochemical parameters showed an asymmetric distribution. The statistical software package used was SPSS 13.0. The accumulated precipitation values $24 \mathrm{~h}$ prior to sample collection were obtained from the automatic station of the Bauru Meteorological Center (IPMet).

\section{Results and discussion}

Physicochemical parameters

The physicochemical parameters of the samples are presented as box plots in Figs. 1 and 2. In these figures, the solid lines represent the value or the range of values for the respective parameter, found in raw domestic sewage (railing) (Von-Sperling 2005). In some graphs, the reference lines are not presented because the Brazilian legislation does not contemplate reference values for such parameter. 

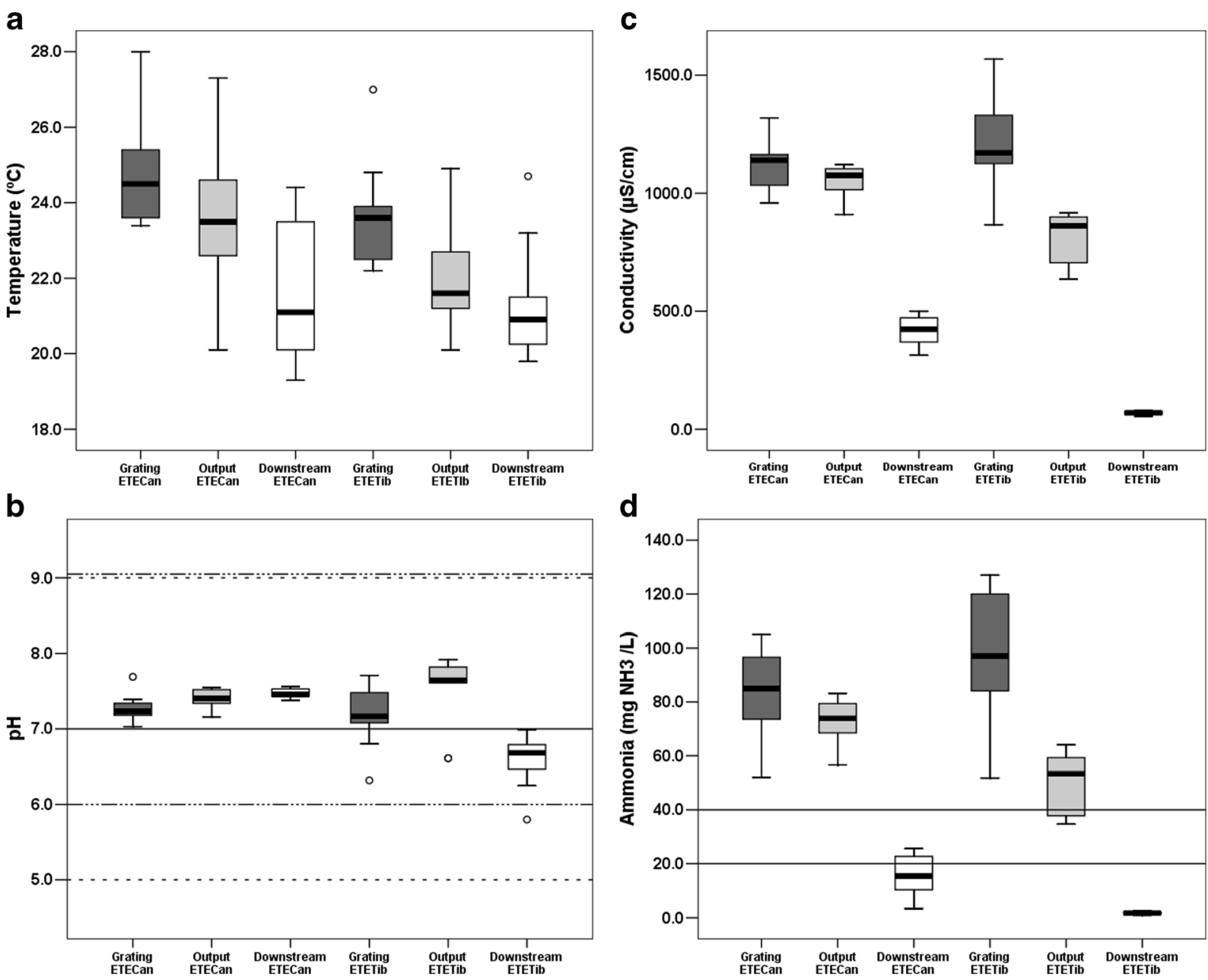

Fig. 1 Box plots of the values found for a temperature, $\mathbf{b} \mathrm{pH}, \mathbf{c}$ conductivity, and $\mathbf{d}$ ammonia content in Candeia and Tibiriçá sewage treatment plants. White circles represent outlier levels. Dashed lines represent the standard values established for the

The temperature variation was verified in the WWTPs presenting temperature values in the range of 19 to $28^{\circ} \mathrm{C}$. According to the literature, the temperature is related to organic matter and dissolved oxygen (Fiorucci and Benedetti-Filho 2005). According to Fig. 1a, it is observed that for the two WWTPs, the average temperature of the railing is higher than that of the downstream, possibly due to the higher absorption of heat by the organic matter present in the raw sewage. The temperature data are in agreement with the results obtained from the analysis of dissolved oxygen (Fig. 2c). It is possible to observe, for the two treatment stations, that dissolved oxygen levels are close to 0 in the railing, where there is a correlation between the decrease of DO and treated effluent (output) (CONAMA 2011). Dots/dashed lines represent the default values set for freshwater + treated effluent (downstream) for freshwater bodies of class II

temperature increase (Fiorucci and Benedetti-Filho 2005). The $\mathrm{pH}$ values presented in Fig. $1 \mathrm{~b}$ for the two WWTPs indicate a range between 5.8 and 7.9, values within the limits established by the legislation (CONAMA 2005) and consistent with the results obtained in other studies (Alves et al. 2008).

Figure 1c shows the conductivity values for the samples, ranging from 54.9 to $1568.0 \mu \mathrm{S} \mathrm{cm}^{-1}$. The electrical conductivity is directly related to ions dissolved in an aqueous medium, so that the greater the amount of ions, the greater the conductivity of the water analyzed. This is an important parameter for evaluating water quality, since in general, sites with conductivity levels greater than $100 \mu \mathrm{S} \mathrm{cm}^{-1}$ can be classified as impacted regions (Alves et al. 2008; Oliveira and Cunha 2014; Gomes 
Fig. 2 Box plots of the variables a turbidity, b COD, and c dissolved oxygen at the Candeia and Tibiriçá sewage treatment plants. White circles represent outlier levels. Dashed lines represent the standard values established for the treated effluent (output) (CONAMA 2011) .

Dots/dashed lines represent the default values set for freshwater + treated effluent (downstream) for freshwater bodies of class II
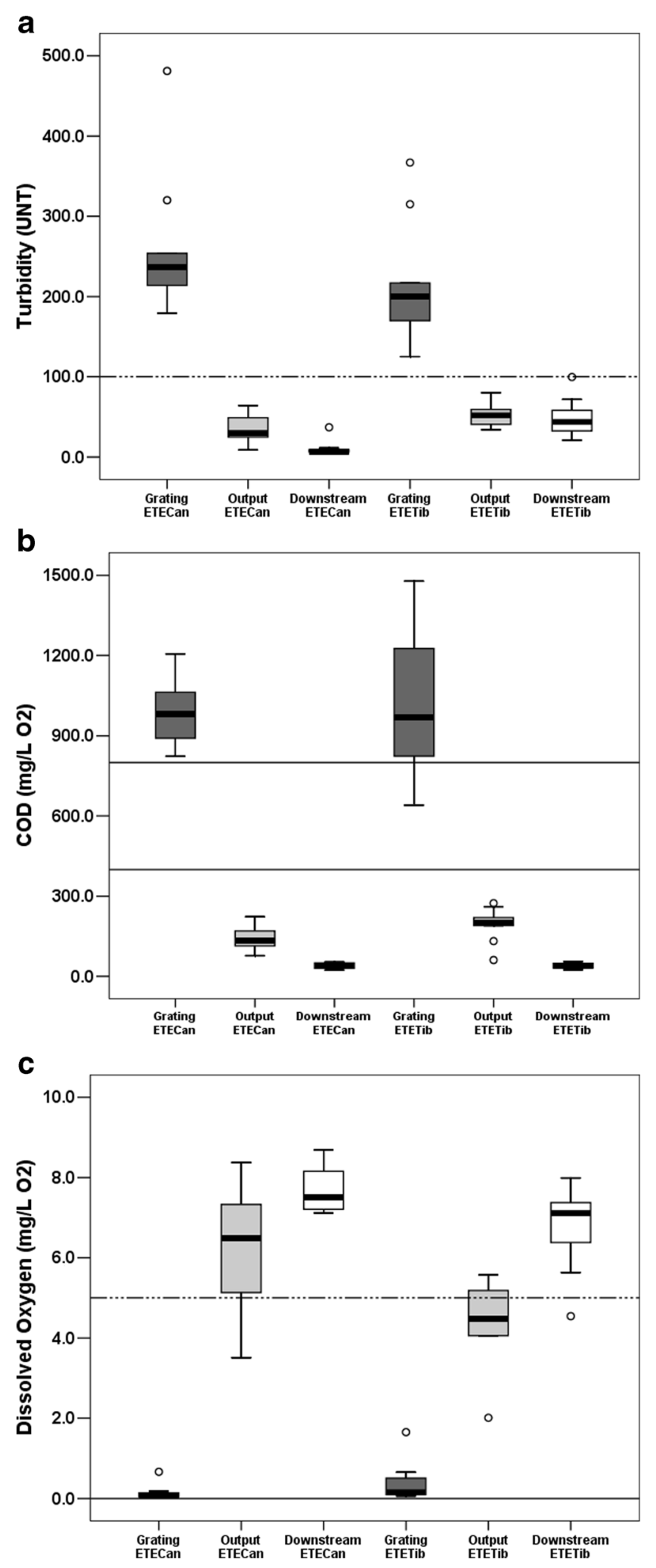
et al. 2017). In this study, only downstream ETETib presented lower conductivities than $100 \mu \mathrm{S} \mathrm{cm}^{-1}$; however, when comparing the values of railing and downstream, it is observed the efficiency in the removal of ions from the sewage treatment process of the stations evaluated.

Another physicochemical factor of relevance to evaluate the quality of the water is the concentration of ammonia, as this is an indication of recent pollution in the bodies of water (Alves et al. 2008). According to Fig. 1d, it is possible to observe average values of 84.3 and $96.1 \mathrm{mg} \mathrm{NH}_{3} \mathrm{~L}^{-1}$ on the railing of WWTPs ETECan and ETETib, respectively, and in the downstream of these same stations mean values of 15.7 and $1.7 \mathrm{mg}$ $\mathrm{NH}_{3} \mathrm{~L}^{-1}$. In the railing, the incoming effluents present several compounds (organic and inorganic) containing ammonia in their composition, showing a greater amount of organic matter and consequently a greater pollution of the water bodies, different from what was observed for the results for treated effluent (output). From these perspectives, it is possible to observe again the efficiency and importance of sewage treatment plants.

Figure 2a shows turbidity values of the treated sewage in the two WWTPs. The turbidity is also able to classify impacted regions once the passage of light is interrupted causing all aquatic life to be threatened (Alves et al. 2008). The results showed that the turbidity is above the legal limit (100 UNT) for the samples in the railing. This increase must be related to the high level of organic matter, according to Fig. 2b. After the treatment carried out in the WWTPs, the downstream values are below the limit required by the legislation, thus evidencing the efficiency of the process.

Figure $2 \mathrm{~b}$ shows the values related to the chemical oxygen demand (COD), a parameter of extreme importance to evaluate the amount of organic matter present in the sewage or bodies of water, thus being fundamental to assess the degree of pollution of the aquatic environment (Jordão 2005). The values presented show a similar behavior to the turbidity, since COD values in the raw sewage were higher than those of the output and downstream, behavior opposite to the levels of dissolved oxygen (DO), observed in Fig. 2c.

Metal concentration

The main metals found in the ETECan and ETETib sewage samples were $\mathrm{Ba}, \mathrm{Mn}, \mathrm{Zn}, \mathrm{Cu}, \mathrm{Se}, \mathrm{Fe}$, and $\mathrm{Al}$.
These metals can come from various sources such as fertilizers, cleaning products, or factories located outside the industrial site of the city. Another source to be considered is the chemicals used in the treatment of water such as hydrated lime to obtain the final $\mathrm{pH}$ of treated water, sodium chloride used for disinfection, and sodium orthopolyphosphate to inhibit the formation of scale in distribution pipelines, among others (Alves et al. 2008; Oliveira and Cunha 2014). It is also possible that high concentrations of iron may possibly come from obsolete pipelines.

Figure 3 shows the concentrations observed for each metal and the rainfall index $24 \mathrm{~h}$ prior to collection, according to the date and place of sampling. In this figure, (Fig. 3a-f), it is observed that, in general, the concentrations of the metals in the outputs and downstream are smaller than those in the railings, indicating that the sewage treatment performed in the WWTPs, although not aimed at the treatment and removal of metals, in some way promotes the reduction of its levels.

In Fig. 3, it is possible to observe that the concentrations of metals $\mathrm{Zn}, \mathrm{Mn}$, and $\mathrm{Ba}$ are below the limit for discharges of treated effluent in class II water bodies, as opposed to $\mathrm{Al}, \mathrm{Cu}$, and $\mathrm{Fe}$ that are above the maximum limit allowed for output (CONAMA 2005). Metals with concentrations above the permitted levels imply a greater concern due to the great toxicological potential of these elements, which can compromise human health, being its accumulation risk factor for a series of diseases from nausea to heart disease, Alzheimer's disease, and cancer (Campbell 2002; Capellini et al. 2008; CETESB 2013). On August 7, one can see high amounts of some metals ( $\mathrm{Zn}, \mathrm{Mn}, \mathrm{Al}, \mathrm{Cu}$, and $\mathrm{Fe}$ ) only at ETECan. On August 25, the same event observed for the metals (Mn and $\mathrm{Zn})$ and the other metals $(\mathrm{Al}, \mathrm{Cu}$, and $\mathrm{Fe}$ ) presented higher values on September 1.

These events may be related to the illegal disposal of several compounds that end up in ETECan. However, it is worth mentioning that even in high concentrations in the railing, after the treatment carried out by the WWTP, the levels of metals were below or close to the values required by the legislation.

Also in Fig. 3, it is observed that in some cases, metals such as zinc, barium, iron, and aluminum were observed to be higher downstream when compared to the output. The presence of these elements not only in the sewage, but also in the class II water bodies, can be associated to several factors, such as soil leaching and wet deposition of metals present in the air pollution 

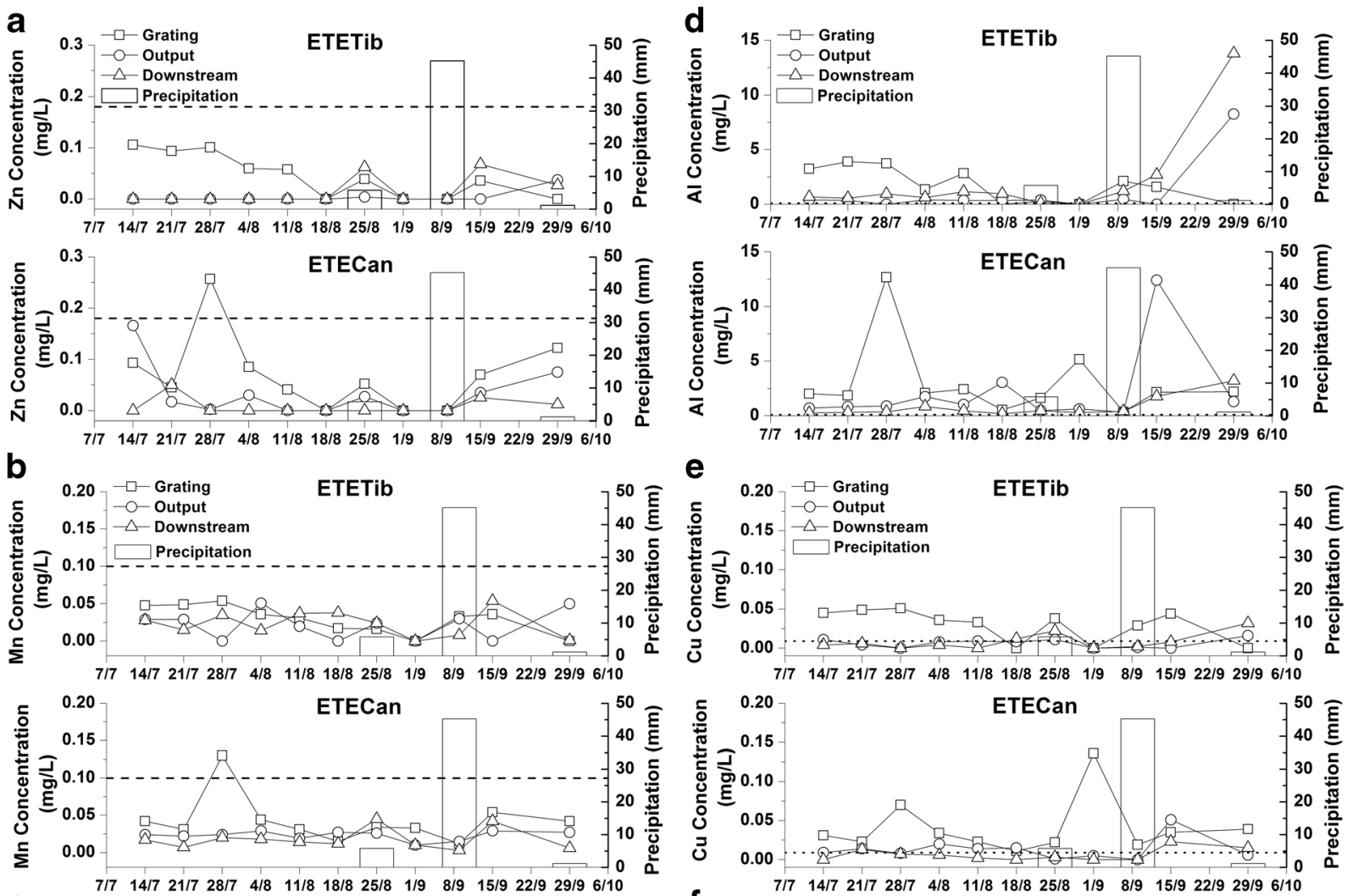

C
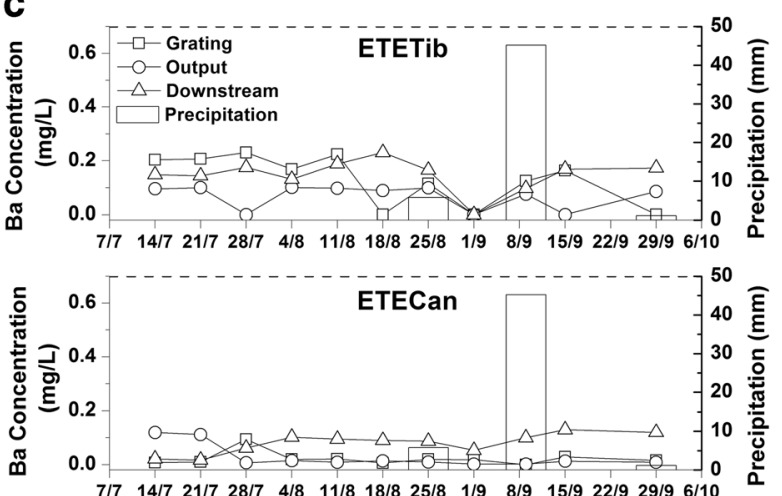

Fig. 3 Concentration of the metals and rainfall index $24 \mathrm{~h}$ before in the two WWTPs in the sampling period. a Zinc. b Manganese. $\mathbf{c}$ Barium. d Aluminum. e Copper. f Iron. Dashed line, maximum

(wash-out fraction), and mainly due to irregular discards (Förstner and Wittmann 2012). The presence of precipitation due to rainfall influences the concentrations of the compounds (organic and inorganic) found in water bodies. The increase in concentration is due to the leaching of these compounds. In Fig. 3a-f, it can be observed, in most cases, an increase in the concentration of metals in days after precipitation events (Gomes et al. 2017).
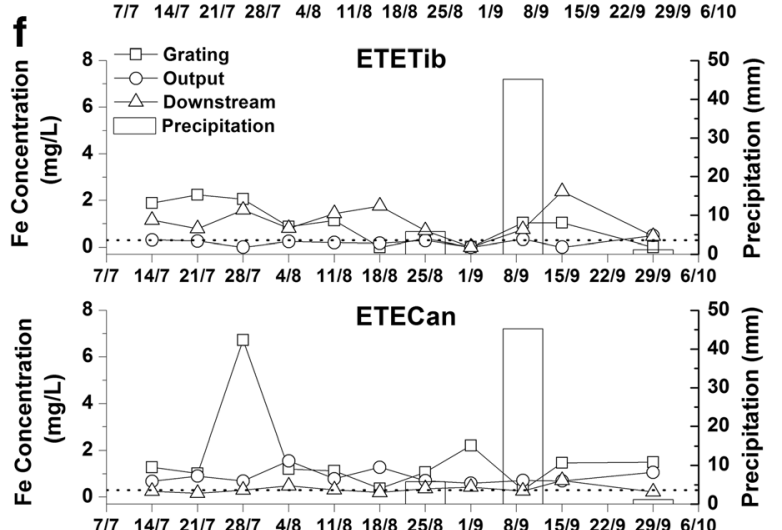

concentration limit for output. Variability of the data was between 10 and $15 \%$ for all samples

Correlation between the evaluated parameters

Tables 1 and 2 present the results of the Spearman correlation tests for the analyzed variables $(\mathrm{pH}$, temperature, conductivity, turbidity, COD, dissolved oxygen, ammonia, and $\mathrm{Mn}, \mathrm{Al}, \mathrm{Cu}, \mathrm{Zn}, \mathrm{Fe}$, and $\mathrm{Ba}$ contents in WWTP).

It can be observed that, as expected, most of the chemical parameters, such as temperature, $\mathrm{pH}$, 


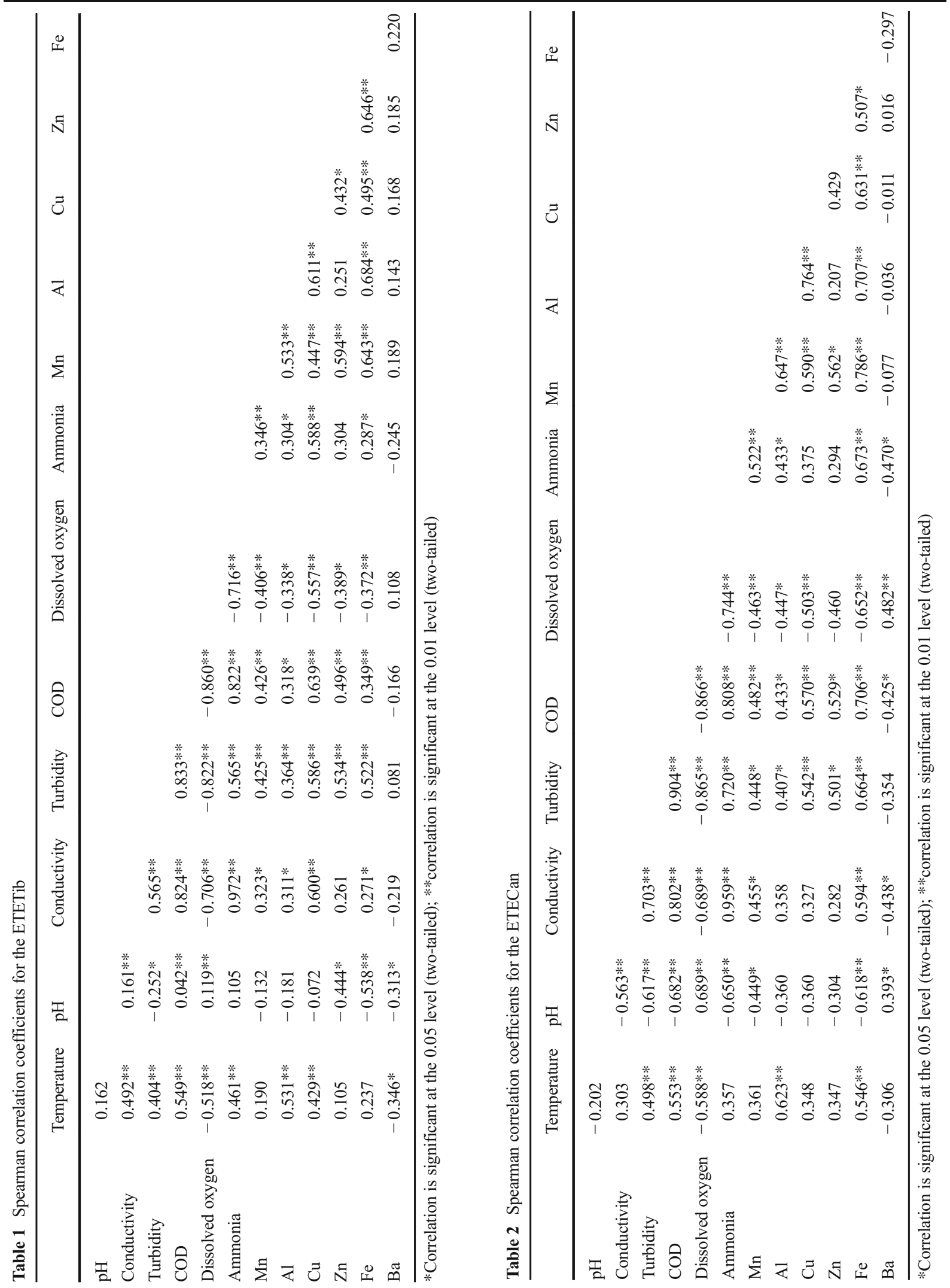


conductivity, turbidity, COD, DO, and ammonia, are correlated with each other. The negative correlation of the temperature with the dissolved oxygen is justified by the fact that with the increase of the temperature there is a decrease of the concentration of DO in aqueous medium due to the high molecular agitation that affects the surface tension of the liquid and facilitates the exit of this gas to the atmosphere (gas exchange). Consequently, one can also see an increase in conductivity, since the ionic activity of a solution is strongly dependent on temperature $(\sim 2 \%$ increase every ${ }^{\circ} \mathrm{C}$ ) (Esteves 2011).

The positive correlation of COD with turbidity and ammonia concentration indicates that the increase in turbidity is a consequence of the increment of the organic matter in the particulate matter in the water, also raising the concentrations of ammonia (present in organic matter) (Alves et al. 2008). The negative correlation between COD and DO is also justified by the high levels of organic matter present in water bodies that consumes the available oxygen (Alves et al. 2008; Oliveira and Cunha 2014).

The positive correlation between the concentrations of the metals with turbidity and COD can be related to the presence of metals in the organic matter, since the studied metals can interact with the organic matter by physical and/or chemical interactions (adsorption, chelates, and complexes) (Alves et al. 2008; Oliveira and Cunha 2014).

Studies concerning hydrogenionic potential $(\mathrm{pH})$ are also crucial to better understand the quality of the water and various chemical processes involved, since the decomposition of organic matter can alter the $\mathrm{pH}$ and interfere with aquatic environment contributing to the precipitation of heavy metals (Alves et al. 2008; Oliveira and Cunha 2014). The results of this study show a negative correlation between $\mathrm{pH}$ and metal concentration, which corroborates the hypothesis that metals are directly associated with organic matter, since low $\mathrm{pH}$ supports its decomposition. In the correlation results, it is noted that DO is negatively correlated with all metals (except $\mathrm{Ba}$ ), indicating that the presence of high concentrations of metals may act by sequestering or reacting with free oxygen in aqueous medium, thus decreasing their concentration through of redox reactions (Miranda et al., 2009).

In general, it should be noted that the high presence of metals has an impact on practically all physicochemical parameters together and/or is a consequence of the alteration of these same parameters. This indicates that the analysis of the metal levels can be considered when analyzing the physicochemical parameters.

\section{Conclusion}

The results showed an increase in temperature variation, consequently a decrease of the dissolved oxygen, and an increase of the organic matter, as shown by the COD results. The results obtained in the railing for turbidity and COD showed values above the legal limit, while the results of electrical conductivity showed above $100 \mu \mathrm{S} \mathrm{cm}^{-1}$ for all collected points (grating, output, and downstream) except for downstream of ETETib, indicating an impacted region. The treatment of the stations was efficient due to the decrease of the physicochemical parameters obtained at the output and downstream of the WWTP studied. The concentrations of the metals $\mathrm{Zn}, \mathrm{Ba}$, and $\mathrm{Mn}$ are below the legal limit for water bodies, whereas the metals $\mathrm{Al}, \mathrm{Cu}$, and $\mathrm{Fe}$ are above the legal limit. The correlation between the physicochemical indices and the levels of metals suggest that guidelines of different physicochemical parameters consider the levels of metals for the establishment of water quality indices. It is important to consider that the anthropic action, the main cause of the high concentrations of metals in the aquatic environment, can significantly affect the physicochemical parameters, since high concentrations of metals can interfere mainly in the $\mathrm{pH}, \mathrm{COD}$, and DO factors. Therefore, it is fundamental and important that in the routine analyses in sewage, the levels of metals should also be quantified, since high concentrations of metals can interfere mainly in the $\mathrm{pH}$, chemical oxygen demand, and dissolved oxygen.

Acknowledgments The authors thank to Elieni G. Pinheiro and Gabriel A. Canevari for the technical assistance.

Funding information This study was funded by FAPESP-São Paulo Research Foundation (grant number 2015/22864-2).

\section{Compliance with ethical standards}

Conflict of interest The authors declare that they have no conflict of interest. 


\section{References}

Alves, E. C., Silva, C. F., et al. (2008). Avaliação da qualidade da água da bacia do rio Pirapó - Maringá, Estado do Paraná, por meio de parâmetros físico, químicos e microbiológicos. Acta Scientiarum Technology, 30(1), 39-48.

APHA (2005). Standard methods for examination of water and wastewater. United States of America, American Public Healthy Association.

Campbell, A. (2002). The potential role of aluminium in Alzheimer's disease. Nephrology Dialysis Transplantation, 17, 17-20.

Capellini, V. L. M. F., Rodrigues, O. M. P. R., Melchiori, L. E., \& Valle, T. G. M. . (2008). Crianças Contaminadas por Chumbo: estudo comparativo sobre desempenho escolar. Estudos em Avaliação Educacional, 19(39), 155-180.

CETESB (2013). Ficha de Informação Toxicológica. Divisão de Toxicologia, Genotoxicidade e Microbiologia Ambiental.

CONAMA (2005). Resolução CONAMA N ${ }^{\circ} 357 / 2005$ Publicação DOU n ${ }^{\circ}$ 053, de 18/03/2005, Ministério do meio ambiente, Conselho nacional do meio ambiente.

CONAMA (2011). Resolução CONAMA N ${ }^{\circ} 430 / 2011$ Publicação DOU n ${ }^{\circ} 92$, de 16/05/2011, pág. 89 Ministério do meio ambiente, Conselho nacional do meio ambiente.

Conover, W. (1980). Practical nonparametric statistic. New York, John Whiley \& Sons.

de Vives, A. E. S., Moreira, S., Brienza, S. M. B., Medeiros, J. G. S., Filho, M. T., Zucchi, O. L. A. D., \& Filho, V. F. N. (2006). Monitoring of the environmental pollution by trace element analysis in tree-rings using synchrotron radiation total reflection X-ray fluorescence. Spectrochimica Acta Part B: Atomic Spectroscopy, 61(10-11), 1170-1174.

El Samrani, A. G., Lartiges, B. S., et al. (2008). Chemical coagulation of combined sewer overflow: Heavy metal removal and treatment optimization. Water Research, 42(4-5), 951-960.

Englert, N. (2004). Fine particles and human health - a review of epidemiological studies. Toxicology Letters, 149(1-3), 235-242.

Esteves, F. A. (2011). Fundamentos De Limnologia, Editora Interciência.

Fiorucci, A. R. and E. Benedetti-Filho (2005). A importância do oxigênio dissolvido em ecossistemas aquáticos. Química nova na escola 22: 10-16.

Förstner, U. and G. T. W. Wittmann (2012). Metal pollution in the aquatic environment, Springer Science \& Business Media.
Gomes, V. M., Magdalena, A. G., et al. (2017). Study of mobility and environmental contamination by chromium from tannery industry in two streams in the Town of Dobrada in the state of São Paulo, Brazil. Revista Virtual de Química, 9(5), 1840-1852.

IBGE (2016). Estimativas da população residente nos municípios brasileiros, Ministério do Planejamento, Desenvolvimento e Gestão.

Järup, L. (2003). Hazards of heavy metal contamination. British Medical Bulletin, 68(1), 167-182.

Jordão, C.P., Pereira, M.G., et al. (2005). Influence of domestic and industrial waste discharges on water quality at Minas Gerais State, Brazil. Journal of the Brazilian Chemical Society 16(2), 241-250.

Khan, T. A. (2011). Trace elements in the drinking water and their possible health effects in Aligarh City, India. Journal of Water Resource and Protection, 3(7), 522-530.

Kumar, R., Rani, M., Gupta, H., \& Gupta, B. (2014). Trace metal fractionation in water and sediments of an urban river stretch. Chemical Speciation and Bioavailability, 26(4), 200-209.

Miranda, R. G., Pereira, S. D. F. P., et al. (2009). Quality of water resources in the Amazon region- Rio Tapajós: assessing the case for chemical elements and physical-chemical parameters. Ambiente e Agua - An Interdisciplinary Journal of Applied Science, 4(2), 18.

Mulchandani, A., \& Westerhoff, P. (2016). Recovery opportunities for metals and energy from sewage sludges. Bioresource Technology, 215, 215-226.

Nriagu, J. O., \& Pacyna, J. M. (1988). Quantitative assessment of worldwide contamination of air, water and soils by tracemetals. Nature, 333(6169), 134-139.

Oliveira, B. S. S., \& Cunha, A. C. (2014). Correlação entre qualidade da água e variabilidade da precipitação no sul do Estado do Amapá. Revista Ambiente \& Água, 9(2), 261-275.

Vasconcellos, P. C., Balasubramanian, R., Bruns, R. E., SanchezCcoyllo, O., Andrade, M. F., \& Flues, M. (2007). Watersoluble ions and trace metals in airborne particles over urban areas of the state of Sao Paolo, Brazil: Influences of local sources and long range transport. Water Air and Soil Pollution, 186(1-4), 63-73.

Von-Sperling, M., Chernicharo, C. A. L. (2005). Biological wastewater treatment in warm climate regions. London: IWA Publishing. 